A N N A L ES

UNIVERSITATIS MARIAE CURIE-SKŁODOWSKA

LUBLIN - POLONIA

VOL. LXVI, 1

SECTIO G

2019

Uniwersytet Jagielloński w Krakowie

BOGDAN SZLACHTA

bogdan.szlachta@uj.edu.pl

ORCID: 0000-0003-4841-589X

\title{
Św. Ireneusz z Lyonu a Melito - o niektórych problemach chrześcijańskich „myślicieli politycznych doby męczenników”
}

St. Irenaeus of Lyons and Melito - on Some Problems of Christian 'Political Thinkers During Martyrs Era'

Odsyłając Czytelnika do wywodów w artykule pt. Chrześcijańska refleksja polityczna ,doby męczenników” na tle tradycji antycznych (wprowadzenie do badań), które mogłyby stanowić interesujący wstęp do niniejszego tekstu, ukazując podejście chrześcijan połowy II w. po Chr. obejmujące namysł obecny już wcześniej, a dotyczący ewentualnego istnienia wspólnej dla chrześcijan i władców rzymskich hołdujących politeizmowi (dbających w jakiejś mierze i o tradycję, i o trwałość prawa, i o zachowanie roli „czynnika religijnego”) podstawy normatywnej ${ }^{1}$, podejmę poniżej próbę przedstawienia uwag o nieco późniejszych propozycjach. W przywoływanym tekście zwracałem uwagę, że pisma św. Justyna Męczennika (zwanego też Filozofem, 100?-165?) wywarły szczególny wpływ nie tylko na (omawianego tam) Tertuliana, ale także na przedstawionego poniżej św. Ireneusza z Lyonu. Justyn nie odwoływał się do „,prawa Bożego” ani „,naturalnego", lecz do prawa obowiązującego w Rzymie, wiążącego również chrześcijan, krytykując praktyki karania wyznawców Chrystusa nie za uczynki, lecz za hołdowanie nieuznawanej wierze. $\mathrm{W}$ istocie zbliżał się on tym samym do Cycerona (który niekiedy bywa przedstawiany jako prekursor „zasady rządów prawa”), uznając, że prawo wiąże wszystkich obywateli bez względu na ich wyznanie i zapewnia im jednakowe uprawnienia. Wskazując, że rzeczą prawa jest porządkowa-

1 B. Szlachta, Chrześcijańska refleksja polityczna ,,doby męczenników” na tle tradycji antycznych (wprowadzenie do badań), [w:] Jak patrzeć na Polske, Niemcy i świat? Księga jubileuszowa profesora Eugeniusza Cezarego Króla, red. J. Szymoniczek, Warszawa 2017, s. 387-410. 
nie aktów zewnętrznych, a nie motywów, Justyn istotnie dotykał punktu zajmującego prawników nie tylko swego czasu, nie zauważając jednak, że: pragnienie chrześcijan „roztoczenia przed wszystkimi poglądu na ich życie i nauki” staje naprzeciw życia i nauk tych, którzy coraz wyraźniej czczą ,geniusz cesarza”, a przezeń nadto „geniusz państwa”; zestawiając swą naukę o Bogu jedynym z nauką o jedynym władcy, uosabiającym ,geniusz państwa” i wymagającym boskiej czci, nie może żądać wkomponowania w istniejącą strukturę normatywną Najwyższego, przekraczającego porządek polityczny; ubóstwiany władca, uznawany przez niektórych - choćby przez Diona Chryzostoma - za swoistą ,inkarnację prawa”, nie jest w stanie sankcjonować obecności Kogoś, kto go przekracza i z którego rozumu lub woli można wywodzić normy i miary także jego woli, nie dokonując zasadniczej zmiany nie tylko systemu prawnego, ale i kategorii opisujących klasyczne „państwo”, uzasadniających ów system. Jednak warto zauważyć, że apel Justyna, by chrześcijanie dawali się poznawać dla uniknięcia „,kary za tych, którzy by błądzili z niewiadomości", łączył się z innym apelem, skierowanym do władców rzymskich albo szerzej - do wyznawców klasycznej koncepcji „państwa”: „[...] waszą jest rzeczą - pisał Męczennik - jak tego zresztą rozum wymaga, wysłuchać nasze wywody i stać się sędziami sprawiedliwymi. Jeśli bowiem po takim wyświetleniu sprawy jeszcze się sprawiedliwością rządzić nie będziecie, nie znajdziecie uniewinnienia wobec Boga"2, którego sądu nikt nie uniknie i który będzie surowy dla „trwających w niesprawiedliwości”3. Nie negując państwa rzymskiego, lecz apelując do bezinteresownych sądów, Justyn usiłował przekonać władców, że Królestwo, którego oczekują chrześcijanie, nie stanowi zagrożenia dla ich „państwa”, że wyznawcy Chrystusa wiernie spełniają obowiązki publiczne i są posłuszni prawu jednakowemu dla wszystkich obywateli, a ich nauka moralna jest użyteczna dla cesarzy i całej ludzkości, mimo że nie pozwala na ubóstwianie władców politycznych ${ }^{4}$.

Podobne stanowisko, jak podnosiłem w przywołanym powyżej tekście, zajmował Tertulian, zdaniem którego szacunek i służba cesarzowi są uzasadnione przez to, że jest on zaledwie drugi po Bogu, Jemu zawdzięcza swe posłannictwo, posiada władzę przez Niego ustanowioną. W wypowiedziach obu apologetów można odnaleźć wyraźny zarys koncepcji politycznej: oto Bóg jest Jedynym, od którego pochodzi stworzenie, obejmujące i bogów wszystkich poza Nim, i ludzi; to On miał ukształtować stworzenie i w nim przewidzieć miejsce także dla jednostek politycznych, dla których ustanowił władztwo i dla których wskazał jego piastunów, przed Nim ostatecznie ponoszących odpowiedzialność za swoje

2 Św. Justyn, Apologia. Dialog z Żydem Tryfonem, Poznań 1926, I, 3.

Ibidem, I, 68.

4 Ibidem, I, 12 i 21. Zob. także: F. Dvornik, Early Christian and Byzantine Political Philosophy. Origins and Background, Vol. 2, Washington 1966, s. 588-589. 
poczynania. Między Bogiem Jedynym i władcami przez Niego ustanowionymi nie ma pośredników, władcy ci są bowiem „,więksi” tak od wszystkich innych ludzi, jak i od „bogów”, również podlegających Bogu. Ta monistyczna koncepcja nie przewiduje zatem „dwoistości” Bożo-człowieczej ani możliwości podziału „świata politycznego" między dwie dziedziny, a przez to - jak się wydaje - nie przewiduje możliwości wydzielenia dwóch ,porządków”, ma bowiem władcę posiadającego legitymację bezpośrednio od Boga za jedynego ewentualnego dawcę prawa w ,planie doczesnym” i jedynego jego ,rządcę”; ,rządcę” powołanego nie tylko do „karania występnych”, ale też - przynajmniej postulatywnie - do ,prowadzenia poddanych do zbawienia".

Działający nieco wcześniej niż Kartagińczyk Tertulian, św. Ireneusz (Irenaeus, 130?-202), pochodzący ze Wschodu (urodzony niedaleko syryjskiej Smyrny) biskup galijskiego Lugdunum (Lyonu), uchodzi za twórcę podobnego stanowiska. Uznawany niekiedy za sprawcę przeniesienia na Zachód idei bliskich Kościołowi działającemu w Azji Mniejszej, podobnie jak inni chrześcijanie swoich czasów nie był wolny od millenarystycznych nadziei; tak jak Tertulian formułował jednak uwagi odbiegające od negującego istniejący „świat polityczny” stanowiska często przypisywanego św. Janowi i jego naśladowcom. Przywołując Pawłowy List do Rzymian, Ireneusz uznawał królestwa tego świata za dzieło Boga, a nie szatana; odnosił się tedy krytycznie do propozycji składanych przez gnostyków: powołując się na zalecenie Jezusa, nakazywał płacić podatki; wskazując, że serce króla pozostaje w rękach Stwórcy, że - jak jednoznacznie orzekł Jahwe za pośrednictwem Salomona - królowie mają władać i wymierzać sprawiedliwość, działając w imieniu Tego, który ich ustanawia, przekonywał, iż każdy poddany winien być posłuszny władcom jako „narzędziom Boga”. Wydaje się, że mimo narzucającego się podobieństwa ujęcie Ireneusza odbiega w pewnym zakresie od tego znajdowanego u Tertuliana - owszem, władza pochodzi od Boga Jedynego, jest elementem Jego stworzenia, okazuje się atoli (i jest to jeden z najbardziej kontrowersyjnych elementów namysłu chrześcijańskiego, wyraźny, a kontrowersyjny nawet w szesnastowiecznej refleksji politycznej na Zachodzie), że równie jednoznacznie niepodobna przypisać Boskiej legitymizacji każdemu jej piastunowi, że Jedyny nie nadaje wprost legitymacji każdemu władającemu. Co więcej,

5 Pisał św. Ireneusz gwoli zarysowania najistotniejszego argumentu, którego chrześcijanie będą mogli używać przeciwko uproszczonemu „gnostycyzmowi politycznemu” przez wiele następnych stuleci: ,[...] nie on [szatan] ustanowił królestwa tego świata, lecz Bóg: »Albowiem serce króla w ręku Boga« (Przyp. 21,1). [...] Diabeł bowiem, ponieważ jest aniołem apostatą, potrafi zrobić tylko to, co odkrył w początkach [rodzaju ludzkiego], tj. zwodzić i kusić umysł ludzki do przekraczania przykazań Bożych i krok za krokiem zaślepiać serca tych, którzy by chcieli służyć Bogu, żeby zapomnieli o prawdziwym Bogu, a kłaniali się jemu jakby bogu [...]. I nastawiał się coraz bardziej wrogo do człowieka, a bo mu zazdrościł życia i chciał go zamknąć pod swoją władzą odszczepieńczą" - Przeciwko herezjom, V, 24, cyt. za: Antologia patrystyczna, red. A. Bober, Kraków 1965, s. 55. 
celem realizowanym przez władcę - znów inaczej niż u Tertuliana - nie jest już prowadzenie poddanych ku dobru, lecz raczej (i tylko) powstrzymywanie tych spośród nich, którzy popełniają występki (negatywny raczej, i tylko, niż pozytywny cel poczynań władających). U Ireneusza zadanie prowadzenia ku dobru zostaje wyraźniej przekazane wspólnocie wierzących w Chrystusa, która ma teraz znać „miary sprawiedliwości”. To element nieobecny u Tertuliana, kreślącego swoistą „wizję monistyczną" i przydającego piastunowi władztwa bezpośrednio Boską legitymizację, a przez to wikłającego się w trudny problem rozpoznawania miar sprawiedliwości przez „inną instancję” niż władca polityczny z Bogiem związany bezpośrednio.

Zdaniem Ireneusza, autora zapowiadającego w pewnej mierze dążenie do typowej później dla Zachodu „koncepcji dualistycznej”, właśnie w związku z kwestią nie podjętą przez Tertuliana, wspólnota wiernych jest zorganizowana wokół biskupa Rzymu jako głowy Kościoła:

[...] największego i najstarszego i wszystkim znanego, przez dwu najchwalebniejszych Apostołów Piotra i Pawła założonego i ustanowionego w Rzymie, który posiada tradycję od Apostołów i wiarę opowiadaną ludziom, a dochodzącą aż do nas drogą kolejnego następstwa biskupów. Z tym bowiem Kościołem [tj. Kościołem w Rzymie] dla jego naczelnego zwierzchnictwa musi się zgadzać każdy Kościół, tj. wszyscy zewsząd wierni, bo w nim przez tych, co są zewsząd, zachowała się tradycja apostolska ${ }^{6}$.

Było to orzeczenie o tyle istotne, że za życia Ireneusza i Tertuliana szerzyły się co najmniej trzy osobliwe opcje, których zwolennicy przekonywali o swoich racjach w pewnej mierze pomimo tego, co Ireneusz nazwał „tradycją apostolską" i co skojarzył z Kościołem rzymskim. Pierwsza z tych opcji związana była z nauczaniem Marcjona, który - jak podaje Jaroslav Pelikan:

[...] zerwał więzi pomiędzy objawieniem chrześcijańskim a Starym Testamentem, odseparował apostoła Pawła od reszty apostolskiej wspólnoty, przypisał mu całą wiedzę o chrześcijańskiej prawdzie na temat związku pomiędzy Prawem a Ewangelią oraz interpretował rozwijające się chrześcijaństwo katolickie jego czasów jako odstępstwo od prawdziwie apostolskiego, czyli Pawłowego nauczania ${ }^{7}$.

Stanowisko Marcjona było dla Ireneusza o tyle kłopotliwe, że nie uwzględniało znaczenia św. Piotra, na którym również, i w pierwszej kolejności, miała się wspierać „rzymska tradycja apostolska”. Zwolennicy drugiego stanowiska, gnostycy $^{8}$, radykalizowali „dysjunkcję pomiędzy stworzeniem a odkupieniem

6 Przeciwko herezjom, III, 2, s. 39.

7 J. Pelikan, Tradycja chrześcijańska. Historia rozwoju doktryny, t. 1: Powstanie wspólnej tradycji (100-600), Kraków 2008, s. 113.

8 Omawiając starożytną perską myśl polityczną, Wiktor Kornatowski (Zarys dziejów myśli politycznej starożytności, Warszawa 1968, s. 56-58) zauważa, że gnostycy wyrastają z tradycji zo- 
i uczynili z niej ontologiczną zasadę zakorzenioną w samej boskiej naturze". Już to stwierdzenie problematyzuje ich związek z akceptującą istniejący świat polityczny „tendencją św. Pawła”, która przecież - z uwagi na wagę jego nauczania - winna być bliska Marcjonowi. Widać, że on i gnostycy nie zmierzali zapewne w tę samą stronę; gnostycy przypisali apostołom Chrystusa ,pedagogiczne dostosowanie do błędnych wzorów myślowych ich czasów, co oznaczało, że prawdziwa gnoza nie mogła być przekazana bezpośrednio przez apostolskie pisma”. Było to uderzenie w samo sedno „idei tradycji apostolskiej”, która miała zapewniać prawdziwość przekazu Chrystusa, zapośredniczonego jedynie w nauczaniu Jego apostołów. Twierdząc, że „prawdziwa gnoza” może być odkrywana wyłącznie dzięki swoistej gnostyckiej hermeneutyce oraz że nie mogła i nie może się ujawniać w nauczaniu apostołów i ich ewentualnych następców, gnostycy głosili, że otrzymali swoją doktrynę dzięki im przypadającej ,prawdziwej sukcesji, powszechnemu nauczaniu tego, co ostatecznie zaczęło być postrzegane [...] jako główny, ortodoksyjny nurt doktryny"9. Zwolennicy trzeciej opcji - montaniści, do których zbliżył się wspomniany już Tertulian w 206 r., a przystał do nich w 213 r. jeszcze bardziej jednoznacznie niż Marcjon prezentowali wizję „upadku Kościoła od czasów apostolskich”, który miał być spowodowany „przez światowość jego życia i kompromisy w nauczaniu”. Zdaniem montanistów „prawdziwa sukcesja apostolska należała do tych, którzy, podobnie jak apostołowie, nadal otrzymywali szczególne objawienia obiecane im przez Chrystusa i za ich pośrednictwem wszystkim kolejnym pokoleniom w Kościele". Przedstawiciele każdego z tych systemów, a zatem marcjonici, gnostycy i montaniści, jak konkluduje Pelikan, twierdzili, że „utrzymywali autentyczną ciągłość nauki i że katolickie roszczenie do ciągłości”, którego eksponentem miał się stać św. Ireneusz z Lyonu, „było bezprawne" 10 . Ireneusz, millenarysta, jak niemal wszyscy apologeci II i III w. nie podzielał zapatrywań montanistów, którzy - a wśród nich krytykujący Marcjo-

roastryzmu, rozwijanego nie tylko w kierunku mitraizmu (skupionego wokół kultu Mitry, istotnego jeszcze w IV w. po Chr., gdy cesarz Julian Apostata podjął próbę wykorzystania go jako środka służącego do walki z chrześcijaństwem) i nie tylko w kierunku monistycznym (bliskim szczególnie grupie zerwanitów czy zurwanitów, którzy usiłowali pogodzić dwie potęgi: dobra i zła, w jedną całość w ogarniającym wszystko nieskończonym czasie lub nieskończonej przestrzeni, jako swoistych praprzyczynach obu tych mocy), ale także właśnie w skrajnie dualistycznym kierunku, jakim miał być gnostycyzm.

9 J. Pelikan, op. cit., s. 114.

${ }_{10}$ Ibidem. Dodajmy na marginesie, że w szczególności montaniści, których stanowisko z pewnością w pewnym zakresie ewoluowało, powoływali się na Parakleta jako źródło swej wiedzy czy odczuć, czym narażali się biskupom pretendującym wszak do pozycji głównych, jeśli nie jedynych, piastunów autorytetu świadczącego o tożsamości wyznawców Chrystusa. Zob. w szczególności: G.D. Dunn, Tertullian, London 2004, s. 6; Ch. Trevett, Montanism. Gender, Authority, and the New Prophecy, Cambridge 1996, s. 146-149. Zob. również: T.D. Barnes, Tertullian. A Historical and Literary Studies, Oxford 1971, passim. 
na Tertulian $-\mathrm{z}$ entuzjazmem oczekiwali na nadejście Pana, dążąc do zbudowania eschatologii dokonującej się w konkretnej, a niedalekiej przyszłości. Miało to odzwierciedlenie w podejściu do Kościoła, który Ireneusz ujmował jako apostolski i hierarchiczny, Tertulian zaś, nieprzywiązujący wagi do kwestii sukcesji biskupów w Kościele-Duchu, miał Kościół, jak inny rygorysta - Hipolit Rzymski (skądinąd jedyny antypapież uznany za świętego), za „świętą społeczność żyjących w prawości”, nieznajdującą miejsca dla heretyków i grzeszników, których miał jakoby tolerować biskup Rzymu Kalikst $\mathrm{I}^{11}$.

Jeśli dostrzeżemy, że zaprzeczenie łączności pomiędzy Chrystusem a Starym Testamentem, dokonane przez Marcjona, wynikało z jego wrogości wobec Stwórcy i stworzenia, którą wyraźnie podzielali zwolennicy chrześcijańskiego gnostycyzmu, to zdołamy uchwycić odmienność wobec nich montanistów podobnych Tertulianowi, eksponujących znaczenie nowego proroctwa, a przez to pomniejszających znaczenie proroctwa dawnego, czy to chrześcijańskiego, czy żydowskiego. Zwalczając marcjonitów, św. Ireneusz przekonywał, że i apostołowie, i ich uczniowie nauczali tak, jak nauczał Kościół o kwestiach dotyczących nie tylko różnicy, lecz także jedności i harmonii pomiędzy Starym a Nowym Testamentem. Ponieważ apostołowie, których Chrystus wyznaczył na ,świadków każdego czynu i każdej katolickiej nauki” (Przeciw herezjom 3,12,13), traktowali Prawo Starego Testamentu jako rozporządzenie tego samego Boga, którego poznali w Chrystusie, utrzymywali łączność z „pierwszym Testamentem” ${ }^{2}$. Pragnąc uzasadnić istotę „tradycji apostolskiej”, Ireneusz negował wszystkie trzy opcje (głównie jednak marcjonizm i gnostycyzm) jako stanowiska krytyczne wobec tradycji Starego Testamentu, ukazujące św. Pawła w polemice z prawem mojżeszowym. Czyniąc to, potwierdzał znaczenie tradycji starotestamentowej dla tradycji apostolskiej również ze względu na potrzebę ukazania nie tylko łączności, ale i ciągłości między stworzeniem a odkupieniem. Zdaniem Ireneusza Kościół na całym świecie zachowuje tradycję otrzymaną od apostołów, która głosi, że jeden jest Bóg, który stworzył niebo i ziemię, zajmowaną w szczególności przez różne wspólnoty polityczne znające „czynnik władczy”. Podobną tezę głosił Tertulian, zwracając się przeciw marcjonitom i podkreślając, że w tym zakresie honorował to, co Pelikan nazywa ,pierwszym kryterium” czy „,momentem ośrodkowym sukcesji apostolskiej”: ciągłość Boga jako Stwórcy i jako Odkupiciela, jako Tego,

11 Papież ten nie tylko naraził się Kartagińczykowi Tertulianowi i Rzymianinowi Hipolitowi, lecz także zapewne wielu innym Rzymianom, gdy pozwolił chrześcijankom zawierać ważne przed Bogiem związki małżeńskie z mężczyznami o niższym statusie społecznym, choć rzymskie prawo cywilne związków takich nie uznawało. Zob. szerzej: W.N. Carroll, Historia chrześcijaństwa, t. 1: Narodziny chrześcijaństwa, Wrocław 2009, s. 482-484. Była to, jak pisze przywoływany autor, „,kościelna deklaracja niezależności od państwa w kwestii sakramentu małżeństwa - historyczna chwila w historii stosunków pomiędzy Kościołem a świeckimi instytucjami władzy” (ibidem, s. 483).

12 J. Pelikan, op. cit., s. 116. 
który ukształtował stworzenie, a w nim czynnik władczy i z nim kojarzone wspólnoty polityczne, i jako Tego, który podjął dzieło odkupienia piastunów władztwa i uczestników rządzonych przez nich wspólnot. Drugą formą ciągłości w tradycji apostolskiej była łączność, w jakiej pozostawali apostołowie ze sobą jako wierni posłańcy nowiny Chrystusa oraz ze św. Pawłem, w istocie uznawanym przez Marcjona za jedynego apostoła, a nawet za tego, który nie przyjął błędnego nauczania uczniów wybranych w trakcie ziemskiego życia przez Jezusa. Odpowiedzią Kościoła na takie wyniesienie Pawła przeciwko apostołom:

[...] było przypisanie apostolskiego autorytetu i władzy całej wspólnocie apostołów oraz kanonowi Nowego Testamentu, a w konsekwencji nacisk na fakt, że nie istniał żaden konflikt między nauczaniem Pawła a nauką innych apostołów. „Piotr był apostołem tego samego Boga, co Paweł” - deklarował Ireneusz, a Tertulian potwierdzał, że „Piotr dorównuje Pawłowi w śmierci męczeńskiej”. [...] Założeniem tej zgodności był pogłębiający się autorytet normatywnego korpusu pism, w którym [...] nie tylko Paweł i Piotr, ale także cała wspólnota apostołów dawała wyraz jednej wierze apostolskiej ${ }^{13}$.

Cały Kościół w każdym miejscu na świecie miał swoje podstawy w osobach apostołów, co miało kapitalne znaczenie nie tylko przy próbach znajdowania „apostolskich fundatorów” najważniejszych Kościołów i ewentualnych sporach o prymat w związku z ustanowieniem przez „ważniejszego apostoła”, lecz także w procesie „dochodzenia” do scentralizowanego jednego Kościoła, niebędącego tylko związkiem odrębnych gmin ${ }^{14}$; Kościoła przy tym, w którym - inaczej niż u gnostyków - ma trwać tradycja pochodząca od apostołów, zachowywana dzięki następstwu prezbiterów ${ }^{15}$; w odróżnieniu od tradycji gnostyków tradycja apostolska miała się „,zachowywać publicznie” w Kościołach, które utrzymywały apostolską sukcesję i łącznośćc ${ }^{16}$.

13 Ibidem, s. 116-117.

14 Ibidem, s. 118-119.

15 Ireneusz z Lyonu, Przeciwko herezjom, 3,2,2.

16 J. Pelikan, op. cit., s. 121. Historyk ten uzupełnia: „Dla Ireneusza Bóg w Chrystusie był zarówno źródłem, jak i treścią tradycji. Chrystus przekazał swoim uczniom tradycję, zgodnie z którą Ojciec jest jednym jedynym Bogiem. Ten jeden jedyny Bóg głoszony przez proroków i prawdziwą Ewangelię był Bogiem kochanym i czczonym przez chrześcijan. Kościół otrzymał tę tradycję od apostołów i przekazał ją kolejnym pokoleniom. W odróżnieniu od tajemnej nauki gnostyków, przekazywanej jedynie wybranym, w odróżnieniu od nowego proroctwa montanistów, które oddzielało ich od wspólnoty z innymi braćmi, ta apostolska tradycja była ogłaszana niczym obwieszczenie miejskiego herolda. Charakterystyczne dla apostołów było to, że naukę, którą otrzymali od Chrystusa, przekazywali otwarcie wszystkim, nie dyskryminując nikogo. Tradycja apostolska była tradycją publiczną; apostołowie nie przekazywali jednego zbioru nauk w tajemnicy, a drugiego otwarcie, ukrywając część swojej tradycji tak, aby była przekazywana w drodze szczególnej sukcesji jedynie elicie gnostyckiej" (ibidem, s. 121-122). I wreszcie znaczący cytat potwierdzający te uwagi, pochodzący z tekstu Ireneusza Przeciwko herezjom: „Prawdziwą gnozą jest nauka Apostołów oraz wiara Kościoła w jej całości znana od dawna na całym świecie. Wyróżniającym znakiem Ciała Chry- 
Stanowiska Tertuliana i Ireneusza to pierwsze przykłady względnie rozbudowanej refleksji chrześcijan o ,świecie politycznym”. Wskazanie Tertuliana, by traktować cesarza jako „drugiego po Bogu”, jako tego, który nie ma konkurentów wśród śmiertelników (ani nawet wśród „bogów”), którego władzy nie może ograniczać ani kontrolować żadna doczesna instytucja, jest pokrewne monizmowi hellenistycznemu, choć nie uwzględnia, a nawet jest krytyczne wobec prób ubóstwiania władcy lub wspólnoty politycznej ${ }^{17}$. Nowe elementy pojawiają się w wypowiedziach autora współczesnego wymienionym, którego uwagi uznawane są niekiedy za bardziej charakterystyczne dla myślenia chrześcijan schyłku II w. niż uwagi Tertuliana i Ireneusza. W apologii pochodzącej z około 176 r., adresowanej do cesarza Marka Aureliusza, biskup Sardyki Melito nie tylko potwierdzał tezę o naturalnym walorze i użyteczności „państwa” (niebędącego „tworem szatana", jak mogliby twierdzić gnostycko nastawieni dualiści), lecz także twierdził, że chrześcijaństwo może dać Rzymowi duchową moc, zdolną go umocnić „politycznie”. Pax Augusti był pokojem, który umożliwił narodziny chrześcijaństwa, następcy Oktawiana winni tedy być świadomi, że rozwój ich państwa i rozwój chrześcijaństwa, rozpoczęte w tym samym okresie, winny przebiegać równolegle. $\mathrm{W}$ innej apologii, przypisywanej niekiedy temu samemu autorowi, znajdujemy wprawdzie powtarzany przez chrześcijan zakaz ubóstwiania władców doczesnych, formułowany jednak obok tezy, iż sam Stwórca napełnia umysł cesarza, że jego osoba odzwierciedla Osobę Boga w planie doczesnym, a jego „państwo" cieszy się pokojem, gdy zna on i obawia się prawdziwego Boga, podlegając Jego wyłącznemu osądowi. Choć ostatnia teza znajdowana jest też u Tertuliana, to u tamtego autora brak równie jednoznacznej deklaracji o wydźwięku hellenistycznym, wręcz czyniącej pogańskiego władcę swoistym „pasem transmisyjnym" woli Boga chrześcijan wobec doczesnego planu; rozwiązanie przyjęte przez Melita dodatkowo komplikowało problem, który dostrzegliśmy u Tertuliana: uzasadnienia pozycji ewentualnej instancji zdolnej ocenić działania władcy ${ }^{18}$.

Uwagi Melita, sformułowane w piśmie do Marka Aureliusza, skłaniają do zatrzymania się choćby na chwilę na stanowisku samego władcy rzymskiego (uchodzącego wszak za „filozofa na tronie”). Jest to usprawiedliwione o tyle, że Marek kreśli koncepcję opartą, jak się zwykle przyjmuje, na tradycji stoickiej, niezwykle

stusa jest następstwo biskupów, którym Apostołowie przekazali Kościół znajdujący się w danym miejscu. Ta troska trwa aż do naszych czasów, bez fałszowania Pisma Świętego, w najpełniejszym wykładzie, którego się nie uzupełnia ani nie uszczupla. Czyta się je bez fałszowania. Według Pisma Świętego następuje prawidłowy i sumienny wykład bez bluźnierstwa, a przede wszystkim jako dar miłości, dar, który jest cenniejszy od gnozy, chwalebniejszy niż proroctwo i przewyższający inne charyzmaty" $(4,33,8)$.

17 F. Dvornik, op. cit., s. 583-584.

18 František Dvornik (ibidem, s. 586) sugeruje nawet, że fragment ten w wielkiej mierze oddaje rozumowanie charakterystyczne dla późniejszych prac przedstawiających ideał chrześcijańskiego władcy w rodzaju słynnego Fürstenspiegel. 
ważnej dla Rzymian, w tym dla rzymskich prawników, którzy odwoływali się do niej, bo sięgali do ustaleń Cycerona. Co więcej, Marek może być traktowany jako jeden $\mathrm{z}$ autorów ustalających wizję, której głównym walorem jest hierarchia lub gradacja; wizję ważną również - choć zapewne inaczej rozwijaną - dla licznych chrześcijańskich autorów następnych stuleci. Cesarz zdaje się bronić stanowiska, zgodnie z którym świat jest uporządkowany, o ile pozostaje w zgodzie z naturą (Naturą) mającą walor rozumności. Ruch skierowany przeciw naturze ma być tym, który współczesny badacz myśli Marka uznaje za jedyny zdolny zakłócić występujący w świecie powszechny ruch łączenia się, w tym doprowadzić do aspołeczności człowieka; nie podejmując rozważań nad tym, na ile ruch ten mógł stwierdzać cesarz u chrześcijan, na ile mógł on ich mieć za tych, którzy sprzeciwiają się wymaganiom natury i dlatego są nierozumni, wskażmy jedynie, że zdaniem Marka ,prawdziwym rządem pozostają rządy natury, której człowiek nie może się sprzeciwić, iż społeczna natura człowieka jest kluczowym, stale powracającym motywem całej jego filozofii"; co więcej, iż byty zajmujące tzw. niższe szczeble natury podporządkowane są tym, które są znajdowane ponad nimi, zatem na „wyższych szczeblach”. Ten ,porządek wertykalny” czy „,pionowy” jest jednak dopełniany przez Marka Aureliusza przez „porządek poziomy” właściwy istotom wyższym, harmonizowanym na mocy porozumienia, które nie wymaga świadomie składanych oświadczeń woli, skoro realizowane jest także przez nieświadomych jego treści:

[...] nawet ktoś bezrozumny, kto nie pojmuje celu i próbowałby stanąć na zawadzie przeznaczeniu - orzeka „cesarz-filozof” - jest w istocie włączony w porządek świata, w którym od zawsze miał swoje miejsce [...]. Wyrzuty i opór bezrozumnego [...] nie zagrażają zatem Światu, są czymś w rodzaju niekoniecznego naddatku, który jakby uzupełnia porządek świata, nic w nim nie zmieniając, przeciwnie nawet - przyczyniając się doń.

Wynika z tego, że bezrozumny (czyżby także chrześcijanin, może nawet Melito?) „,zachowuje się jakby był odłączoną cząstką, ale nie jest nią w rzeczywistości. Mielibyśmy więc tu do czynienia z charakterystyką określającą jedynie pewien stan psychiczny i indywidualny, skutek złudnego przekonania, że można się przeciwstawić biegowi natury”. Z uwagi tej wynikałoby jednak, że „odcięcie się” lub „odłączenie” jest jedynie pozorne czy powierzchowne, choć oznacza nienaturalne wyrzeczenie się „czynnego współrządzenia światem”, skoro „człowiek, czyli ten, który utrzymuje swoją godność człowieka, istoty boskiej, jest nie tylko częścią świata, lecz także - i zwłaszcza - członkiem, uczestnikiem rządów boskich poprzez swe posłuszeństwo prawu naturalnemu i [poprzez] swoje działanie"19.

W państwie rządzonym przez cesarza myślącego w ten sposób miejsce chrześcijan, tak jak wszystkich innych ludzi, winno być po stronie tych, którzy uczestni-

19 V. Laurand, Marek Aureliusz a polityka, [w:] Teoria i praktyka polityczna Marka Aureliu$s z a$, red. K. Marulewska, Warszawa 2010, cytaty ze s. 66-74. 
czą w „rządach boskich”, rządach jednak - i w tym zdaje się tkwić główny problem - inaczej myślanych przez władców rzymskich i przynajmniej część wyznawców Chrystusa w dobie prześladowań. Być może w tym właśnie miejscu dotykamy kwestii zasadniczej - idzie o wykład treści rozumności kojarzonej z bogami lub Bogiem, a obecnej w świecie doczesnym, postulatywnie ujawniającej się $\mathrm{w}$ treści norm prawnych, w tym norm obowiązujących w politeistycznym Rzymie, nieznośnych dla chrześcijan. Jeśli dostrzeżemy, że jako przynajmniej „częściowy” stoik Marek Aureliusz opierał się „na całkowicie racjonalnych argumentach” i dlatego nie znajdował żadnego miejsca „na objawienie, które mogłoby dodać nowe treści do tych dostarczanych przez rozum" "20, to lepiej zrozumiemy powody napięć między Rzymianami podobnymi cesarzowi i Rzymianami, którzy przyjęli wiarę w Chrystusa, a wraz z nią niestoickie przeświadczenie o znaczeniu treści objawionych przez Boga; zrozumiemy też lepiej przyczyny długo trwającego i zapewne nierozstrzygalnego sporu o podstawy prawodawstwa znajdowane tylko w rozumie (woli?) człowieka lub przynajmniej po części w orzeczeniach Boga.

\section{BIBLIOGRAFIA}

Antologia patrystyczna, red. A. Bober, Kraków 1965.

Barnes T.D., Tertullian. A Historical and Literary Studies, Oxford 1971.

Carroll W.N., Historia chrześcijaństwa, t. 1: Narodziny chrześcijaństwa, Wrocław 2009.

Dunn G.D., Tertullian, London 2004.

Dvornik F., Early Christian and Byzantine Political Philosophy. Origins and Background, Vol. 2, Washington 1966.

Kornatowski W., Zarys dziejów myśli politycznej starożytności, Warszawa 1968.

Laurand V., Marek Aureliusz a polityka, [w:] Teoria i praktyka polityczna Marka Aureliusza, red. K. Marulewska, Warszawa 2010.

Pelikan J., Tradycja chrześcijańska. Historia rozwoju doktryny, t. 1: Powstanie wspólnej tradycji (100-600), Kraków 2008.

Rist J., Religijność Marka Aureliusza a chrześcijaństwo, [w:] Teoria i praktyka polityczna Marka Aureliusza, red. K. Marulewska, Warszawa 2010.

Szlachta B., Chrześcijańska refleksja polityczna „doby męczenników” na tle tradycji antycznych (wprowadzenie do badań), [w:] Jak patrzeć na Polskę, Niemcy i świat? Księga jubileuszowa profesora Eugeniusza Cezarego Króla, red. J. Szymoniczek, Warszawa 2017.

Św. Justyn, Apologia. Dialog z Żydem Tryfonem, Poznań 1926.

Trevett Ch., Montanism. Gender, Authority, and the New Prophecy, Cambridge 1996.

20 J. Rist, Religijność Marka Aureliusza a chrześcijaństwo, [w:] Teoria i praktyka politycz$n a$..., s. 129. Zauważając, że Marek Aureliusz nie rozpoczął oficjalnego prześladowania chrześcijan, bo zapoczątkowano je dopiero w 248 r. za panowania Decjusza, autor podkreśla, iż „częściowy stoik" sprzyjał nietolerancji wobec chrześcijan, skoro to jego przyjaciel Juniusz Rustyk przewodniczył w 177 r. sądowi w Lyonie, który skazał na śmierć wspomnianego na wstępie tekstu św. Justyna Męczennika (ibidem, s. 135). 


\section{SUMMARY}

Christians of the "martyrs era" (especially during the second century AD), discussed not only their role in the polytheistic world and eventually deified political ruler (emperor) but also the basis of authority and legitimacy of the ruler. St. Irenaeus of Lyons and Melito were written also on existing a possible normative context binding ruler which is non-Christian. The author of the study argues that their positions were not identical, and moreover, to some extent were polemical with the views found in the statements of the emperor Marcus Aurelius.

Keywords: emperor; God; Church; apostolic succession; law

\section{STRESZCZENIE}

Chrześcijanie „doby męczenników” (zwłaszcza II w. po Chr.) spierali się nie tylko o rolę chrześcijan w świecie zdominowanym przez politeizm i ewentualnie ubóstwianego władcę politycznego (cesarza), lecz także o podstawę władzy i legitymację władcy. Św. Ireneusz z Lyonu i Melito pozostawili jednak również wywody dotyczące istnienia ewentualnego normatywnego kontekstu, który obowiązuje też władcę niebędącego wyznawcą Chrystusa. Autor opracowania wykazuje, że ich stanowiska nie były tożsame, a ponadto w pewnym zakresie były polemiczne względem ujęć znajdowanych w wypowiedziach cesarza Marka Aureliusza.

Słowa kluczowe: cesarz; Bóg; Kościół; sukcesja apostolska; prawo 